\title{
Social Media Use During Natural Disasters: An Analysis of Social Media Usage During Hurricanes Harvey
}

\author{
Larry J. King \\ Stephen F. Austin State University \\ P.O. Box 6161 SFA Station \\ Nacogdoches, Texas, USA
}

\begin{abstract}
This paper examines the use of social media in two recent national disasters and provides conclusions about the use of social media in these types of events.
\end{abstract}

Keywords - Social Media, Natural Disasters, Hurricane Harvey, Hurricane Irma

SUGGESTED CITATION: King L. J. (2018). Social media use during natural disasters: An analysis of social media usage during Hurricanes Harvey and Irma. Proceedings of the International Crisis and Risk Communication Conference (pp. 20-23). Orlando, FL, USA. Nicholson School of Communication. https://doi.org/10.30658/icrcc.2018.6

\section{INTRODUCTION}

Two recent natural disasters have demonstrated the power, ubiquity, and potential of social media platforms. During hurricanes Harvey and Irma ordinary citizens, organizations, and governmental entities used social media to communicate a wide variety of messages to several audiences. Some Twitter and Facebook users took to the platforms to coordinate rescues of people trapped in their homes by floodwaters. One desperate mother, Iashia Nelson, in Houston posted messages and videos to Facebook pleading for someone to rescue her family from the roof of their house. Her messages even drew the attention of traditional media, and she did television interviews from the roof of her house as her family waited for rescue. A local television news station, KHOU, was flooded during the hurricane, so the station's reporters started broadcasting news via Facebook Live. These examples led Nikki Usher, Associate Professor of Media and Public Affairs at George Washington University, to call Hurricane Harvey "the first major natural disaster of the social media age"[1]. This paper examines the variety of uses social media during these disasters. Special attention will be given to identifying the social media platforms used and classifying the ways in which social media platforms were used.

\section{METHODS}

To investigate the use of social media during Hurricanes Harvey and Irma, google searches were conducted to identify news stories focusing on examples of the use of social media during the hurricanes. The search terms "Hurricane Harvey," "Hurricane Irma,” "social media,” "twitter," "Facebook,” "Snapchat,” and "YouTube.” Additionally, the author monitored his personal social media accounts to identify instances of individuals and organizations using the social media platforms during the hurricanes. After the news stories and instances from social media were collected, they were examined and categorized based on the use of social media during the hurricanes.

\section{RESULTS}

Five categories of social media use were identified from the news stories and social media posts. These social media use categories were labelled "Securing Rescue,” "Volunteerism,” “Information Sharing,” “Activism,” "Keeping Friends and Family Updated.” 


\section{SECURING RESCUE}

Early during Hurricane Harvey, governmental entities in Houston issued warnings that people should use 911 and other emergency phone numbers if they needed rescue and not social media, but the volume of calls quickly overwhelmed emergency phone lines and services and they were unable to respond to the demand. As the flood waters rose in Houston, it became clear that traditional means of securing rescue were inadequate and people in need turned to social media. Iashia Nelson used Facebook Live and posts to secure rescue for herself, her children, and about a dozen other people from the roof where they were stranded in Houston. She was also interviewed live, via Facetime, from the roof on Good Morning America [2]. Maritza Ritz Willis tweeted, "I have 2 children with me and tge [sic] water is swallowing us up. Please send help.” Later Willis tweeted, "Got picked up bty [sic] the fire rescue, Thank You. One of you had connections and all I can say is I'll be eternally grateful!!!”[1]. D'Antrese McNeil, a FEMA volunteer, said that "Social media played a big part [in our rescue efforts] as people provided addresses for themselves and family members, we were able to provide dispatchers with an address that made it easier to find them" [3]. Owners of La Vita Bella Nursing Home in Dickenson, Texas, twitted a photo of residents of the nursing home setting in waste deep flood water along with a plea for help [4]. After the tweet went viral, rescuers showed up to evacuate the resident. Lauren LeBlanc from Plano, Texas, found out her grandmother was stranded at her home in Houston. LeBlanc used Twitter to connect with a variety of officials from the Coast Guard and Office of Emergency Management, along with everyday citizens with boats. A former high school classmate brought LeBlanc's tweets to the attention of a Houston newscaster, and the newscaster helped to coordinate the rescue of LeBlanc's grandmother [3].

The hashtags \#sosHarvey and \#helphouston were used to let rescuers know that people were in need of help, and the Twitter account @HarveyRescue was created to compile addresses and names of those who needed rescue [1]. Twitter users tweeted the addresses of those who needed rescuing, including details about the number of people and their condition, for those who were working to rescue victims from the floodwaters[5]. The Zello walkie-talkie app used by the Cajun Navy, the volunteer navy of rescuers from Louisiana, during Hurricane Harvey, became the top downloaded app ahead of Hurricane Irma [6]. The Texas Navy and Cajun Navy created and shared a crowdsourced rescue map that allowed users to submit addresses for those who needed to be rescued, to see where people needed to be rescued, and where rescues had been completed [7]. The website CrowdSource Rescue helped facilitate over 7,000 rescues in Houston, and helped Florida residents in need during Irma [8].

\section{VOLUNTEERISM}

Not only were social media platform used for securing rescue, they were also used for soliciting and organizing efforts of volunteers seeking to help those impacted by the hurricanes. D'Antrese McNeil, a FEMA volunteer, wanted to help people so she created a personal social media page "Hurricane Harvey Volunteer Opportunities" to help make people aware of ways to help victims of the hurricane [3]. Shea Serrano, a best-selling author living in Houston who has over 160,000 followers on Twitter, helped to coordinate multiple successful rescue efforts via Twitter and raised over $\$ 130,000$ for those impacted by the storm from his Twitter followers in just days [3]. Facebook pledged to match every dollar raised on Facebook, up to \$1 million, for the Center for Disaster Philanthropy's Hurricane Harvey Recovery Fund [9]. Airbnb encouraged hosts in Northern Florida and Georgia to make rooms on its site available for free to hurricane evacuees, and Uber provided Floridians free rides to shelters [8].

\section{INFORMATION SHARING}

Individuals, governmental agencies, and businesses also used social media platforms to share information during the hurricanes. The City of Houston used Facebook Live to stream press conferences, and Houston area emergency services used social media platforms to keep citizens updated [3]. The Harris County Texas Sheriff's Office, Houston Office of Emergency Management, and the Houston Police Department all used Nextdoor accounts to get information out to residents affected by Harvey [5]. Seminole County Florida officials worked with the social media site Nextdoor to map all of the residences in the seven towns included in the county and in unincorporated areas as well. Ashley Moore, Community Relations Officer for Seminole County, said "The maps we load into Nextdoor allow us to lessen confusion, specifically when a message is only applicable to part of the County" [8]. Lamar University, in Beaumont, Texas, used their Facebook page to keep students and parents updated on hurricane related delays [10]. Federal agencies also used social media to keep the public informed during the hurricanes. FEMA coordinated with social media companies to share disaster information, and the National Oceanic and Atmospheric Administration posted frequent forecast updates on Twitter during Hurricane Irma [8]. Governmental agencies were not the only ones to turn to social media for information, Floridians used GasBuddy, an app that crowdsources gas prices at the pump, to figure out where fuel was still available as they evacuated in the wake of Hurricane Irma [8].

\section{ACTIVISM}

In addition to information sharing, there were those who used social media for the promotion of social activism. A prime example of this is what happened with Joel Osteen's megachurch in Houston. Osteen's Lakewood Church remained closed even as thousands of Houstonians sought refuge from Hurricane Harvey and the flooding that followed. Pictures and videos of Osteen's closed church along with tweets questioning why the church was closed began appearing 
on Twitter on August 28, 2017. Those tweeting the pictures and videos criticized Osteen for not opening his church to evacuees. The tweets which included a variety of attacks on Osteen, quickly went viral, and were picked up in television news reports. This attention lead Osteen to issue statements to the press and eventually open his church to evacuees.

\section{KEEPING FAMILY AND FRIENDS UPDATED}

People also used social media to inform their family and friends about their safety and location during the hurricanes. Many Facebook users posted regular updates on their safety and whereabouts. For example, one of my Facebook friends made regular posts, including pictures, during Harvey updating his followers on his family's safety and condition. By following his updates, we were able to know that his family had been rescued from their flooded home and that they were all safe. Another of my Facebook friends gave his followers detailed accounts of Hurricane Irma and the damage in his neighborhood. Facebook activated the Safe Check feature, which allows users to check in and notify followers of their status, for Harvey and Irma.

\section{CONCLUSION}

There are several takeaways from the various uses of social media during Hurricanes Harvey and Irma. Frist, in Houston, federal and local officials initially warned those needing assistance away from social media to traditional lines of communication like 911. However, 911 and other emergency lines were quickly overwhelmed, and people turned to social media platforms for help. For Irma, Florida officials were proactive in working with social media based on what had happened during Harvey. It is essential that people have multiple ways to get information during disasters. Federal, state, and local agencies need to understand the importance of using social media in disasters and build social media into their disaster plans. Second, agencies also need to recognize that social media users can be of significant help in these situations and need to find ways to capitalize on social media volunteers. Third, social media can also provide emotional support for people in need of rescue. According to Shea Serrano, "It's at least a tiny bit comforting for someone who needs to be rescued to be able to see that people on Twitter or Facebook or whatever are trying to figure out how to get help to them" [3]. Fourth, social media may be valuable in reacting some people that might not be reached by traditional media. For example, undocumented immigrants may be reluctant to use traditional channels like 911, but may feel more comfortable using social media. Fifth, social media my help those who do not know how to or cannot get in contact with emergency rescue services. Sixth, some people may consider information from social media to be more trustworthy than information carried in traditional media. During Harvey, some people felt that official warnings were alarmist, but began to take them seriously after seeing panic spreading on social media. LaDawn Fletcher, a Web content writer and resident of Houston, noted, "I think if people hear things from people they know, they respond better than they do to notices" [3]. Seventh, organizations and agencies need to recognize that the pervasiveness of social media now means that nothing is private, and someone is always watching.

\section{Author Biography}

Larry J. King earned his Ph.D. in Communication from the University of Oklahoma, he is a Professor of Communication at Stephen F. Austin State University and can be reached at lking@sfasu.edu.

\section{REFERENCES}

[1] Rhodan, M. (2017, August 30). 'Please Send Help.' Hurricane Harvey Victims Turn to Twitter and Facebook. Time. Retrieved from http://time.com/4921961/hurricane-harvey-twitter-facebook-social-media/

[2] Good Morning America [Video File]. (2017, August 28). Retrieved from https://www.facebook.com/ABC News/videos/10156232017178812/

[3] Meadows-Fernandez, R. (2017, September 15). What Harvey and Irma taught us about using social media in emergency response. Pacific Standard. Retrieved from https://psmag.com/social-justice/what-harvey-and-irma-taught-about-usingsocial-media-in-emergency-response

[4] Milstein, K. \& Rosenbaum, S. (2017, August 27). 'Need help ASAP.' The story behind the photo of nursing home residents trapped in hurricane flood water. Time. Retrieved from http://time.com/4917743/la-vita-bella-nursing-homedickinson-texas-photo/

[5] Gilmer, M. (2017, August 29). During Harvey, social media rose to the challenge as a force for good. Mashable. Retrieved from https://mashable.com/2017/08/29/social-media-harvey-rescues-force-for-good/\#vhFRPUdPuOqa

[6] Daileda, C. (2017, September 10). A walkie-talkie app is helping people get through hurricanes. Mashable. Retrieved from https://mashable.com/2017/09/10/zello-app-walkie-talkie-hurricane-irma-harvey/\#jm4KA_tFPiqQ

[7] Google Maps. (n.d.). Hurricane Harvey rescue. Retrieved September 18, 2017, from https://www.google.com/maps/d/u/1/viewer?ll=29.868275810180098\%2C-

95.58358157402347\&z=8\&mid=1qmepB5HrFSthl1DyK7lG9slEabY 
[8] MacMillan, D. (2017, September 11). In Irma, emergency responders’ new tools: Twitter and Facebook. The Wall Street Journal. Retrieved from https://www.wsj.com/articles/for-hurricane-irma-information-officials-post-on-social-media1505149661

[9] Cohen, D. (2017, September 1). Facebook on Hurricane Harvey fundraising efforts: \$10 million and counting. Adweek. Retrieved from http://www.adweek.com/digital/facebook-hurricane-harvey-10-million/

[10] Lamar University Facebook Timeline (2017, August 31). Retrieved September 18, 2017, from https://www.facebook.com/LamarUniversity/ 